\title{
HUBUNGAN METODE MENGAJAR DENGAN MINAT BELAJAR DI MTs AISYIYAH UJUNG BELAKANG OLO PADANG
}

\author{
Dinil Abrar Sulthani
}

Universitas Islam Jakarta

dinil_umsb@yahoo.com

\begin{abstract}
This research aims to describe about teaching methode of teachers, learning interest students, and to determine the relationship between teaching method of teachers and learning interest students in MTs Aisyiyah Ujung Belakang Olo Padang. The research used the quantitative descriptive. The technique used to collect data in this study is the observation, the documentation, and the questionnaires. The findings showed that in MTs Aisyiyah Ujung Belakang Olo Padang: 1) teaching method of teachers is not good in presentation in the class, 2) learning interest students is lower, and 3) this study also indicate that relationship between teaching method of teachers and learning interest students.
\end{abstract}

Keywords: teaching method, learning interest, teacher, student

\section{A. Pendahuluan}

Keberhasilan pembelajaran ditentukan oleh keberhasilan pelaksanaan kegiatan belajar mengajar, yakni keterpaduan antara kegiatan pembelajaran dengan kegiatan peserta didik. Pendidik dan peserta didik harus saling mengisi dan berinteraksi baik di dalam maupun di luar kelas, sehingga pembelajaran tidak hanya berlangsung di lembaga formal tetapi kepada yang lebih luas dan fleksibel. Peserta didik dapat menyerap pelajaran lebih banyak ditentukan oleh pendidik tersebut dalam mengajar.

Salah satu usaha untuk mengoptimalkan pembelajaran adalah dengan memperbaiki pola pembelajaran yang banyak dipengaruhi oleh pendidik. Karena pembelajaran adalah suatu sistem, maka perbaikannya pun harus mencakup keseluruhan komponen dalam sistem pembelajaran tersebut. Komponen-komponen yang terpenting adalah tujuan, materi, metode dan evaluasi.

Dalam perumusan tujuan, pendidik perlu merumuskannya dengan jelas dan dapat diukur. Dengan begitu mudahlah bagi pendidik menentukan metode yang dipilih 
Dinil Abrar Sulthani: Hubungan Metode Mengajar dengan Minat Belajar...

guna menunjang pencapaian tujuan yang telah dirumuskan tersebut. ${ }^{1}$ Dengan adanya perumusan tujuan yang jelas maka akan memudahkan bagi pendidik untuk memilih dan memakai metode mengajar apa yang cocok dengan kondisi masing-masing kelas yang para peserta didik berbeda latar belakang.

Pemakaian metode mengajar yang tepat merupakan salah satu upaya meningkatkan kompetensi dan kualitas pendidik dalam menyampaikan materi ajarnya. Untuk meningkatkan kualitas kegiatan belajar mengajar yang dilakukan oleh pendidik, maka pendidik harus memiliki dan menguasai perencanaan kegiatan belajar mengajar dengan baik. Melaksanakan kegiatan yang direncanakan dan bagaimana metode yang akan digunakan di dalam proses belajar mengajar serta usaha-usaha yang dilakukan oleh pendidik untuk meningkatkan kualitas dari kegiatan belajar mengajar. Kesemuanya itu tentu harus diaplikasikan dan diterapkan sedini mungkin sehingga proses pembelajaran dapat berjalan dengan baik dan efisien.

Penerapan metode yang baik dalam proses belajar mengajar akan memberikan dampak yang baik terhadap pencapaian tujuan pembelajaran, baik dari segi peserta didik maupun dari segi pendidik itu sendiri. Namun sebaliknya jika seorang pendidik tidak menggunakan metode yang sesuai dengan materi pembelajaran maka bisa jadi apa yang disampaikan oleh pendidik tidak bisa dipahami oleh peserta didik. Hal ini tentu menjadi hal penting yang harus diperhatikan oleh pendidik dalam penerapan metode mengajar yang dipakai agar jangan terjadi kerancuan dan ketidak sepahaman antara peserta didik yang satu dengan yang lain dalam materi ajar yang disampaikan oleh pendidik.

Kegiatan belajar mengajar harus diintegrasikan antara pendidik yang mengajar dengan peserta didik yang belajar. Terlebih untuk pendidik haruslah memakai metode mengajar yang efektif dan menarik. Mengajar adalah membimbing peserta didik agar mengalami proses belajar. Mengajar yang efektif ialah mengajar yang dapat membawa belajar peserta didik yang efektif pula. ${ }^{2}$

Sebagai contoh dua orang pedagang roti menjual rotinya dengan tampilan yang berbeda, pedagang pertama membuat rasa roti dengan lezat dan bergizi namun dijual dengan tampilan yang kurang menarik, sedangkan pedagang yang lain rasa rotinya

\footnotetext{
${ }^{1}$ Syaiful Bahri Djamarah dan Aswan Rais, Strategi Belajar Mengajar, (Jakarta : PT. Rineka Cipta, 2006), hlm. 73 hlm. 92

${ }^{2}$ Slameto, Belajar dan Faktor-faktor yang Mempengaruhi, (Jakarta: PT. Rineka Cipta, 2010),
} 
kurang lezat dan kurang bergizi namun dijual dengan tampilan yang menarik. Pada dasarnya pembeli (konsumen) akan memilih tampilan yang menarik karena ia belum mengetahui rasa roti yang mana yang lezat dan juga bergizi. Analogi tersebut dapat diibaratkan dalam proses pembelajaran, seperti pendidik yang telah menyiapkan materi dengan matang dan bagus namun kurang menarik dalam penyampaiannya maka peserta didik akan bosan dan enggan untuk mendengarkan materi yang akan disampaikan pendidik.

Dengan adanya interaksi yang dilakukan oleh pendidik dengan peserta didik akan memudahkan proses untuk mecapai tujuan yang diinginkan. DePorter dkk., sebagaimana dikutip oleh Darmasyah, menyatakan :

"Jika pendidik ingin komunitas belajarnya menjadi tempat yang meningkatkan kesadaran, daya dengar, partispasi dan umpan balik, dan pertumbuhan serta tempat emosi dihargai, maka suasana kelas termasuk bahasa yang di pilih, cara menjalin simpati, dan sikap terhadap sekolah serta belajar harusnyalah suasana yang penuh kegembiraan, yang dapat membawa kegembiraan pula pada para peserta didik. Pendidik harus memahami bahwa perasaan dan sikap peserta didik akan terlibat dan perpengaruh kuat pada proses belajarnya."3

Oleh karena itu, kemampuan dan keterampilan pendidik memilih metode mengajar yang tepat untuk menciptakan interaksi menyenangkan sangat menentukan. Cara terbaik untuk berinteraksi dengan peserta didik adalah memahami impian peserta didik terhadap pendidik ideal yang menurutnya mampu memberikan dorongan terbesar dalam belajar. Dengan mengetahui impian para peserta didik dan menggunakan metode mengajar yang tepat akan memudahkan dalam menyampaikan maskud dari sebuah pembelajaran.

Banyak macam metode mengajar yang bisa digunakan pendidik dalam mencapai tujuan pembelajaran. Dalam penggunaan metode terkadang pendidik harus menyesuaikan dengan kondisi dan suasana kelas. Seperti jumlah peserta didik yang banyak sangat mempengaruhi penggunaan metode tersebut. Memilih metode mengajar yang tepat disaat berhadapan dengan kondisi peserta didik yang beraneka ragam, berhadapan dengan peserta didik yang berjumlah besar maka seorang pendidik harus jeli dan tanggap metode mengajar apa yang cocok untuk mengatasi dalam penyampaian materi pelajarannya.

\footnotetext{
${ }^{3}$ Darmasyah, Strategi Pembelajaran Menyenangkan dengan Humor, (Jakarta : Bumi Aksara., 2010), hlm. 50
} 
Dinil Abrar Sulthani: Hubungan Metode Mengajar dengan Minat Belajar...

Metode mengajar yang digunakan pendidik dalam setiap kali pertemuan kelas bukanlah asal pakai, tetapi telah melalui seleksi yang berkesesuaian dengan perumusan tujuan instruksional khusus. Jarang sekali terlihat pendidik merumuskan tujuan hanya dengan satu rumusan, tetapi pasti pendidik merumuskan lebih dari satu tujuan. Karenanya, pendidik pun selalu menggunakan metode yang lebih dari satu. Pemakaian metode yang satu digunakan untuk mencapai tujuan yang satu, sementara penggunaan metode yang lain, juga digunakan untuk mencapai tujuan yang lain. Begitulah adanya, sesuai dengan kehendak tujuan pembelajaran yang telah dirumuskan. ${ }^{4}$

Dengan penggunaan metode mengajar yang tepat oleh pendidik, minat belajar peserta didik juga diperhatikan dan penting dalam menyelaraskan proses untuk mencapai tujuan pembelajaran yang telah ditentukan. Minat merupakan hal yang terpenting yang harus diperhatikan pendidik dalam menguasai kelas dan peserta didik ketika akan menyampaikan bahan pelajaran.

Minat adalah suatu rasa lebih suka dan rasa keterikatan pada suatu hal atau aktifitas, tanpa ada yang menyuruh. Minat pada dasarnya adalah penerimaan akan suatu hubungan antara diri sendiri dengan sesuatu di luar diri. Semakin kuat atau dekat hubungan tersebut, semakin besar minat. ${ }^{5}$ Minat sangat menentukan berlangsungnya proses penerimaan materi secara optimal bagi peserta didik, dengan adanya minat dan rasa bahagia ketika menerima materi akan lebih memudahkan bagi peserta didik menyerap materi pelajaran dan begitu juga sebaliknya jika minat dan rasa kecendrungan suka yang kurang terhadap materi pelajaran atau cara pendidik menyampaikan materi pelajaran maka akan menimbulkan kebosanan dan penyerapan materi tidak maksimal bagi peserta didik.

Penjelasan yang dikemukakan di atas sangat berbeda dengan fenomena yang terjadi dalam proses belajar mengajar di MTs Aisyiyah Ujung Belakang Olo Padang. Mungkin hal ini disebabkan metode mengajar pendidik yang kurang baik dan kurang menarik, di samping itu minat peserta didik yang kurang terhadap materi pelajaran. Akibatnya peserta didik kurang konsentrasi dalam mengikuti pelajaran dan ada pula yang melakukan tindakan yang kurang baik seperti keluar masuk ruangan, berbelanja ke kedai terdekat. Namun pendidik seolah-olah tidak merespon dengan adanya tindakan peserta didik seperti itu.

\footnotetext{
${ }^{4}$ Syaiful Bahri Djamarah dan Aswan Rais, op.cit., hlm. 75

${ }^{5}$ Slameto, op.cit., hlm. 180
} 


\section{B. Metode Penelitian}

Penelitian ini bersifat deskriptif artinya adalah salah satu jenis penelitian yang bertujuan mendeskripsikan secara sistematis, faktual, dan akurat mengenai fakta-fakta dan sifat populasi tertentu, atau mencoba menggambarkan fenomena secara detail. ${ }^{6}$ Menurut Wayan Ardhana, sebagaimana dikutip oleh Rosi, penelitian deskriptif adalah "penjelasan terhadap fakta-fakta yang sudah terjadi (after the fact)."

Fakta-fakta sudah terjadi yang dimaksud dalam penelitian ini adalah fakta-fakta tentang metode mengajar sebagai variabel bebas dan minat belajar sebagai variabel terikat. Salah satu kelebihan rancangan penelitian ini adalah penelitian dapat dilakukan dalam situasi yang wajar tanpa dibuat-buat sebagaimana dalam rancangan eksperimen.

\section{Lokasi Penelitian}

Penelitian ini dilaksanakan pada MTs Aisyiyah Ujung Belakang Olo Padang di Jalan Ujung Belakang Olo No.17, Kota Padang, Provinsi Sumatera Barat.

\section{Populasi dan Sampel}

Populasi adalah salah satu hal yang essensial dan perlu mendapat perhatian dengan saksama apabila peneliti ingin menyimpulkan suatu hasil yang dapat dipercaya dan tepat guna daerah atau objek penelitiannya. ${ }^{8}$ Populasi adalah wilayah generalisasi yang terdiri atas obyek/subyek yang mempunyai kualitas dan karakteristik tertentu yang ditetapkan oleh peneliti untuk dipelajari dan kemudian ditarik kesimpulannya. ${ }^{9}$ Populasi adalah keseluruhan objek penelitian yang terdiri dari manusia, benda-benda, hewan, tumbuh-tumbuhan, gejala-gejala, nilai tes atau peristiwa-peristiwa sebagai sumber data yang memiliki karakteristik tertentu didalam suatu penelitian. ${ }^{10}$ Populasi juga dapat diartikan keseluruhan objek yang ingin diteliti. Oleh karena itu, yang menjadi populasi pada penelitian ini adalah keseluruhan peserta didik MTs Aisyiyah Ujung Belakang Olo Padang yang terdiri dari kelas VII - IX yang berjumlah 114 orang. Peserta didik lakilaki yang berjumlah 66 orang dan peserta didik perempuan yang berjumlah 78 orang.

Untuk lebih jelasnya sebaran dari Peserta didik tersebut dapat dilihat dari tabel berikut ini:

\footnotetext{
${ }^{6}$ A. Muri Yusuf, Metodologi Penelitian, (Padang : UNP Press, 2007), hlm. 83

${ }^{7}$ Rosi Mardayani, "Korelasi Gaya Mengajar Guru terhadap Motivasi dan Aktivitas Belajar Siswa SMA Pertiwi 2 Padang," Skripsi, Pada FAI UMSB Padang, 2010, tidak diterbitkan, hlm. 57

${ }^{8}$ A. Muri Yusuf, op.cit., hlm. 180 hlm. 215

${ }^{9}$ Sugiyono, Metode Penelitian Kuantitatif, Kualitatif dan $R \&$ D, (Bandung: Alfabeta, 2008),

${ }^{10}$ Margono, Metodologi Penelitian Pendidikan, Jakarta : PT.Rineka Cipta, 2009), hlm. 118
} 
Dinil Abrar Sulthani: Hubungan Metode Mengajar dengan Minat Belajar...

Tabel 1. Distribusi Populasi Peserta didik di MTs Aisyiyah

\begin{tabular}{ccccc}
\hline No & Kelas & Laki-laki & Perempuan & Jumlah \\
\hline 1. & VII A & 16 Orang & 14 Orang & 30 Orang \\
\hline 2. & VII B & 16 Orang & 14 Orang & 30 Orang \\
\hline 3. & VIII A & 9 Orang & 16 Orang & 25 Orang \\
\hline 4. & VIII B & 9 Orang & 15 Orang & 24 Orang \\
\hline 5. & IX A & 6 Orang & 11 Orang & 17 Orang \\
\hline 6. & IX B & 10 Orang & 8 Orang & 18 Orang \\
\hline & Jumlah & 66 Orang & $\mathbf{7 8 ~ O r a n g}$ & $\mathbf{1 1 4}$ Orang \\
\hline
\end{tabular}

Sumber : Dokumentasi MTs Aisyiyah Ujung Belakang Olo Padang

Jika kita hanya meneliti sebagian dari populasi, maka penelitian tersebut disebut sampel. Sampel adalah sebagian dari populasi yang terpilih dan mewakili populasi tersebut. ${ }^{11}$ Agar dapat mewakili populasi yang ada maka pengambilan sampel dilakukan berdasarkan pertimbangan sedemikian rupa sehingga relevan dengan rancangan penelitian dan cukup representatif. Dalam penelitian ini, peneliti mengunakan teknik pengambilan sampel dengan clasified random sampling, karena populasi terbagi atas tingkat-tingkat kelas VII, VIII dan IX. Sampel yang diambil dari jumlah populasi 114 orang . Yang terdiri dari peserta didik kelas VII 60 x 30\% = 18 orang, Kelas VIII sebanyak 49 × $35 \%=17,15$, maka dibulatkan menjadi 17 orang, dan kelas IX sebanyak $35 \times 35 \%=12,25$, maka dibulatkan menjadi 12 orang. Jadinya yang menjadi sampel penelitian ini sebanyak 47 orang.

Tabel 2. Distribusi Sampel Peserta Didik di MTs Aisyiyah

\begin{tabular}{ccccc}
\hline No & Kelas & Jumlah & Sampel Uji Coba & Sampel Hasil \\
\hline 1. & VII A & 30 Orang & 4 Orang & 5 Orang \\
\hline 2. & VII B & 30 Orang & 4 Orang & 5 Orang \\
\hline 3. & VIII A & 25 Orang & 4 Orang & 5 Orang \\
\hline 4. & VIII B & 24 Orang & 3 Orang & 5 Orang \\
\hline 5. & IX A & 17 Orang & 3 Orang & 3 Orang \\
\hline 6. & IX B & 18 Orang & 3 Orang & 3 Orang \\
\hline & Jumlah & $\mathbf{1 1 4}$ Orang & $\mathbf{2 1 ~ O r a n g ~}$ & $\mathbf{2 6 ~ O r a n g}$ \\
\hline
\end{tabular}

\footnotetext{
${ }^{11}$ A. Muri Yusuf, op.cit., hlm. 186
} 
Dinil Abrar Sulthani: Hubungan Metode Mengajar dengan Minat Belajar...

\section{Instrumen Penelitian}

Instrumen penelitian adalah suatu alat yang digunakan mengukur fenomena alam maupun sosial yang diamati. Secara spesifik semua fenomena ini disebut variabel penelitian. ${ }^{12}$ Instrumen penelitian adalah alat atau fasilitas yang digunakan oleh peneliti dalam mengumpulkan data agar pekerjaannya lebih mudah dan hasilnya lebih baik, dalam arti lebih cermat, lengkap dan sistematis sehingga lebih mudah diolah.

a. Penyusunan instrumen

Penyusunan instrumen dengan memakai tiga jenis instrumen penelitian yaitu: (a) observasi, atau pengamatan yang merupakan suatu teknik atau cara mengumpulkan data dengan jalan mengadakan pengamatan terhadap kegiatan yang sedang berlangsung. Peneliti melakukan pengamatan tentang fenomena-fenomena yang terjadi dalam proses belajar mengajar di MTs Aisyiyah Ujung Belakang Olo Padang, dengan mengamati fenomena-fenomena tersebut terdapat masalah yang terjadi yang berhubungan tentang metode mengajar pendidik dengan keinginan dan minat peserta didik mengikuti pelajaran. (b) Dokumentasi, yang merupakan suatu teknik pengumpulan data dengan menghimpun dan menganalisis dokumen-dokumen, baik dokumen tertulis, gambar maupun elektronik. ${ }^{13}$ Dokumen-dokumen yang peneliti dapatkan dari pihak sekolah tentang sejarah berdiri, visi misi MTs Aisyiyah dapat membantu melengkapi penelitian untuk menganalisa masalah tersebut lebih lanjut. (c) Angket, adalah serangkaian atau daftar pertanyaan yang disusun secara sistematis, kemudian diisi oleh responden. ${ }^{14}$ Angket yang digunakan dalam penelitian ini adalah angket tertutup. Alasan penggunaan angket tertutup adalah karena peserta didik di MTs Aisyiyah Ujung Belakang Olo Padang telah bisa membaca, menulis dan memahami sehingga pengisian angket sangat dimungkinkan. Angket yang diberikan kepada peserta didik dengan menggunakan pernyataan positif dan negatif. Untuk pernyataan positif apabila peserta didik menjawab "sangat sering" diberi skor empat (4), menjawab "sering" dengan skor tiga (3), menjawab "kadang-kadang" dengan skor dua (2), atau menjawab "tidak pernah" diberi skor satu (1). Untuk pernyataan negatif, apabila peserta didik menjawab "sangat sering"

\footnotetext{
${ }^{12}$ Sugiyono, op.cit., hlm. 102

${ }^{13}$ Nana Syaodih Sukmadinata, Metode Penelitian Pendidikan, (Bandung: PT Remaja Rosdakarya, 2010), hlm. 220-221

${ }^{14}$ Burhan Bugin, Metodologi Penelitian Kuantitatif, (Jakarta: Kencana, 2005), hlm. 123
} 
Dinil Abrar Sulthani: Hubungan Metode Mengajar dengan Minat Belajar...

diberi skor satu (1), menjawab "sering" dengan skor dua (2), menjawab "kadangkadang" dengan skor tiga (3), dan menjawab "tidak pernah" diberi skor empat (4).

Data yang diperlukan dalam penelitian ini adalah data-data mengenai metode mengajar pendidik dan minat belajar peserta didik di MTs Aisyiyah Ujung Belakang Olo Padang. Untuk mendapatkan data tersebut baik data metode mengajar pendidik maupun minat belajar peserta didik dilakukan dengan menyebarkan angket kepada peserta didik.

Redaksi dari jawaban yang tertera dalam sebaran angket diinterpretasikan kepada redaksi yang baik. Seperti untuk metode mengajar pendidik, sangat sering menjadi sangat baik, sering menjadi baik, kadang-kadang menjadi kurang baik, dan tidak pernah menjadi tidak baik. Begitu pula dengan minat belajar, redaksi dari jawaban yang tertera dalam sebaran angket diinterpretasikan kepada redaksi yang baik. Seperti sangat sering menjadi sangat tinggi, sering menjadi tinggi, kadang-kadang menjadi rendah, dan tidak pernah menjadi sangat rendah.

b. Uji coba

Setelah angket tersusun, maka sebelum pengumpulan data yang sesungguhnya dilakukan uci coba instrumen. Uji coba ini dimaksudkan untuk mengetahui validitas dan reabilitas angket sebagai alat pengumpulan data. Uji coba ini dilakukan kepada peserta didik di MTs Aisyiyah Ujung Belakang Olo Padang. Sebaran angket yang diuji cobakan adalah 21 orang dari 47 orang responden.

c. Validitas

Validitas adalah kebenaran suatu pemikiran bahwa pemikiran benar-benar dilakukan. ${ }^{15}$ Menurut Lee J.Crombach, yang dikutip oleh Rosi, validitas instrumen berkaitan dengan derajat yang menunjukkan seberapa jauh instrumen dapat melaksanakan tepat fungsi yang diembankan kepadanya, artinya untuk apa instrumen tersebut disiapkan. ${ }^{16}$ Validitas yang dipakai dalam penelitian ini adalah validitas isi (content validity). Validitas isi adalah derajat jika sebuah tes mengukur cakupan substansi yang ingin diukur. Validitas isi menunjukkan sejauh mana instrumen tersebut mencerminkan isi yang dikehendaki. Pertimbangan menggunakan validitas isi ini adalah

\footnotetext{
${ }^{15}$ Etta Mamang Sangadji dan Sopiah, Metodologi Penelitian - Pendekatan Praktis dalam Penelitian, (Yogyakarta: CV. Andi Offset, 2010), hlm. 145

${ }^{16}$ Rosi Mardayani, op.cit., hlm. 64
} 
karena yang perlu diteliti hal yang sudah diketahui oleh responden. Dan kesanggupan alat penilaian dalam mengukur isi yang seharusnya.

d. Reliabilitas

Reliabilitas adalah suatu alat ukur yang mantap tidak berubah-ubah pengukurannya dan dapat diandalkan karena pengukuran alat ukur berkali-kali akan memberikan hasil serupa. ${ }^{17}$ Reliabilitas instrumen adalah alat pengukur dalam mengukur apa saja yang diukurnya, keterandalan, kestabilan, ketepatan dan keterdugaan, dan kemampuan alat tersebut digunakan akan memberikan hasil yang relatif sama.

\section{Teknik analisis data}

Teknik analisis yang digunakan sudah jelas, yaitu diarahkan untuk menjawab rumusan masalah atau menguji hipotesis yang telah dirumuskan. ${ }^{18}$ Sesuai dengan hipotesis untuk menganalisis dilakukan dengan menggunakan statistik deskriptif yaitu persentasi dengan rumus:

$$
\mathrm{P}=\frac{\mathrm{f}}{\mathrm{N}} \times 100
$$

Keterangan :

$\mathrm{P}=$ Persentasi

$\mathrm{f}=$ Frekuensi

$\mathrm{N}=$ Jumlah Sampel

Sedangkan untuk menjawab pertanyaan rumusan masalah dilakukan dengan teknik korelasi " $r$ " product moment untuk data tunggal, dengan menggunakan rumus adalah:

$$
r_{x y}=n \frac{\sum x y-\left(\sum x\right)\left(\sum y\right)}{\sqrt{\left(n \sum x^{2}-(x)^{2}\right)\left(n \sum y^{2}-(y)^{2}\right)}}
$$

\section{Hasil Penelitian}

\section{Gambaran Umum MTs Aisyiyah}

MTs Aisyiyah Padang ini, didirikan oleh Pimpinan Aisyiyah Padang Barat di bawah koordinator Majelis Dikdasmen Cabang Muhammadiyah Padang Barat. Pada awal berdirinya (1970) bernama PGA Putri 4 Tahun, berlokasi di lantai II Masjid Taqwa

\footnotetext{
${ }^{17}$ Etta Mamang Sangadji dan Sopiah, op.cit., hlm. 145

${ }^{18}$ Sugiyono, op.cit., hlm. 243
} 
Dinil Abrar Sulthani: Hubungan Metode Mengajar dengan Minat Belajar...

Muhammadiyah Jl. Bundo Kandung No.1 Padang. Pada tahun 1975 terjadi musibah runtuhnya bangunan Masjid tersebut, Pimpinan Aisyiyah Padang Barat yang pada waktu itu sebagai Ketua adalah Ibu Hj. Syamsinar mendapatkan tanah dan bangunan yang berlokasi di Jalan Ujung Belakang Olo No.17 Padang, maka dipindahkanlah lokasi pembelajaran PGA Putri 4 tahun yang semula di Jalan Bundo Kandung No.1 Padang ke Jalan Ujung Belakang Olo No.17 Padang.

Berdasarkan Keputusan Menteri Agama RI No.16 Tahun 1978, maka PGA Putri 4 Tahun dilebur menjadi MTs Aisyiyah Padang Barat yang dipimpin oleh Ibu Dra.Hj. Rusfa sampai tahun 1980. Dari tahun 1980 sampai tahun 1988, MTs Aisyiyah Padang dipimpin oleh Ibu Dra. Husniar. Pada tahun 1989 Madrasah ini dipimpin oleh Ibu Dra. Hj. Ruwaida Rasyad sampai tahun 2000 dan setelah itu dilanjutkan oleh Bapak Drs. H. Muslim Hamid sampai sekarang.

Dengan demikan diharapkan MTs Aisyiyah Padang memiliki kemampuan seperti sekolah umum, dengan keistimewaan memiliki kemampuan bidang agama Islam. MTs Aisyiyah Padang sebagai lembaga pembelajaran yang memiliki fungsi penyelenggara pembelajaran agama dan sekaligus pembelajaran umum, serta ditambah demgan kurikulum muatan lokal yaitu Kemuhammadiyahan dan Seni Qur`an. Kurikulum muatan lokal bertujuan menanamkan, menumbuhkan dan meningkatkan kesadaran peserta didik untuk mengamalkan ajaran Islam serta mendakwahkannya secara berorganisasi sesuai dengan petunjuk al-Qur`an dan Sunnah. Melalui pemahaman gerakan, organisasi dan amal usahanya, serta dimaksudkan dapat menjadi kader Muhammadiyah yang merupakan kader pelopor, pelangsung dan penyempurna Amal Usaha Muhammadiyah.

Dalam rangka mencapai tujuan sebagai lembaga pendidikan, MTs Aisyiyah Padang menetapkan visi, misi dan strategi. Visinya adalah "terwujudnya disiplin dalam proses pendidikan dan berakhlak mulia." Sedangkan misinya: (1) mewujudkan Lembaga pendidikan yang Islami dan berkualitas berdasarkan al-Qur`an dan Sunnah; (2) mengembangkan kurikulum yang mampu memenuhi kebutuhan anak didik dan masyarakat; (3) meningkatkan efektifitas pendidik dan tenaga kepembelajaran yang profesional dan memiliki Kompetensi di bidangnya; (4) meningkatkan efektifitas penunjang proses belajar mengajar (PBM) yang dapat menghasilkan lulusan yang berkualitas; (5) meningkatkan keterampilan di bidang intra dan ekstra kurikuler. Adapun strateginya adalah: (1) pemanfaatan sumber daya yang ada dengan semaksimal mungkin serta 
bekerja sama dengan komite madrasah, orang tua dan masyarakat; (2) melakukan koordinasi dengan instansi terkait, baik secara vertikal maupuin horizontal, sehingga dapat berkerja sama dan saling membangun; (3) melakukan inovasi yang kontiniu menuju madrasah yang berkualitas.

MTs Aisyiyah dikelola dengan bantuan dana yang bersumber dari (1) dana BOS, (2) komite madrasah, (3) sumbangan orang tua/wali peserta didik; (4) sumbangan dari donator; dan (5) sumber lain-lain yang halal.

\section{Gambaran Umum Metode Mengajar Pendidik di MTs Aisyiyah Ujung Belakang Olo Padang.}

Untuk mendapatkan gambaran tentang metode mengajar pendidik di MTs Aisyiyah Ujung Belakang Olo Padang, peneliti mencari berapa banyak peserta didik yang menjawab pernyataan sangat sering, sering, kadang-kadang, dan tidak pernah. Kemudian nantinya diklasifikasikan ke metode mengajar. Gambaran metode mengajar pendidik tergambar pada kuisioner berupa pernyataan yang diberikan kepada peserta didik sebanyak 26 responden.

Dari angket yang disebarkan dapatlah hasil ada 5 orang peserta didik yang menjawab metode mengajar pendidik "sangat sering" lalu dikali 100\% dibagi jumlah responden maka dapatlah persentase $19,23 \%$, sebanyak 6 orang peserta didik yang menjawab metode mengajar pendidik "sering" lalu dikali 100\% dibagi jumlah responden maka dapatlah persentase $23,07 \%$, sebanyak 10 orang peserta didik yang menjawab metode mengajar pendidik "kadang-kadang" lalu dikali 100\% dibagi jumlah responden maka dapatlah persentase 38,46\%, dan sebanyak 5 orang peserta didik yang menjawab metode mengajar pendidik "tidak pernah" lalu dikali 100\% dibagi jumlah responden maka dapatlah persentase 19,23 \%. Dari jawaban responden dapat digambarkan pada tabel 3 sebagai berikut:

Tabel 3. Distribusi Frekuensi Skor Metode Mengajar Pendidik MTs Aisyiyah Ujung Belakang Olo Padang

\begin{tabular}{cccc}
\hline Klasifikasi & Interval & Frekuensi & Persentase \\
\hline SS & $53-59$ & 5 & $19,23 \%$ \\
\hline S & $46-52$ & 6 & $23,07 \%$ \\
\hline K & $39-45$ & 10 & $38,46 \%$ \\
\hline TP & $32-38$ & 5 & $19,23 \%$ \\
\hline
\end{tabular}


Dinil Abrar Sulthani: Hubungan Metode Mengajar dengan Minat Belajar...

Selanjutnya dihitung rata-rata (mean) frekuensi metode mengajar pendidik dengan rumus:

$$
\begin{array}{ll}
\text { Mean } & =\frac{\text { Jumlah skor total }}{\mathrm{N}} \\
\mathrm{M} & =\frac{1176}{26} \\
\mathrm{M} & =45,23 \%
\end{array}
$$

Jadi dari mean tersebut dengan nilai rata-rata 45 yaitu terdapat pada interval kedua antara 39-45. Dapat disimpulkan bahwa rata-rata metode mengajar pendidik MTs Aisyiyah Ujung Belakang Olo Padang adalah kurang baik.

\section{Gambaran Umum Minat Belajar Peserta didik MTs Aisyiyah Ujung Belakang Olo Padang}

Untuk mendapatkan gambaran tentang minat belajar peserta didik di MTs Aisyiyah Ujung Belakang Olo Padang, peneliti mencari berapa banyak peserta didik yang menjawab pernyataan sangat sering, sering, kadang-kadang, dan tidak pernah. Kemudian nantinya diklasifikasikan ke minat belajar. Gambaran minat belajar peserta didik tergambar pada kuisioner berupa pernyataan yang diberikan kepada peserta didik sebanyak 26 responden.

Dari angket yang disebarkan dapatlah hasil, ada 1 orang peserta didik yang menjawab "sangat sering" lalu dikali 100\% dibagi jumlah responden maka dapatlah persentase 3,84\%, sebanyak 9 orang peserta didik yang menjawab "sering" lalu dikali $100 \%$ dibagi jumlah responden maka dapatlah persentase 34,61\%, sebanyak 15 orang peserta didik yang menjawab "kadang-kadang" lalu dikali 100\% dibagi jumlah responden maka dapatlah persentase 57,69 \% dan sebanyak 1 orang peserta didik yang menjawab "tidak pernah" lalu dikali 100\% dibagi jumlah responden maka dapatlah persentase 3,84\%. Jawaban responden dapat digambarkan pada tabel 4 sebagai berikut: Tabel 4. Distribusi Frekuensi Skor Minat Belajar Peserta Didik MTs Aisyiyah Ujung Belakang Olo Padang

\begin{tabular}{cccc}
\hline Klasifikasi & Interval & Frekuensi & Persentase \\
\hline SS & $35-40$ & 1 & $3,84 \%$ \\
\hline S & $29-34$ & 9 & $34,61 \%$ \\
\hline K & $23-28$ & 15 & $57,69 \%$ \\
\hline TP & $17-22$ & 1 & $3,84 \%$ \\
\hline
\end{tabular}


Dinil Abrar Sulthani: Hubungan Metode Mengajar dengan Minat Belajar...

Selanjutnya dihitung rata-rata (mean) frekuensi minat belajar dengan rumus:

$$
\begin{array}{ll}
\text { Mean } & =\frac{\text { Jumlah skor total }}{\mathrm{N}} \\
\mathrm{M} & =\frac{731}{26} \\
\mathrm{M} & =28,11 \%
\end{array}
$$

Jadi dari mean tersebut dengan nilai rata-rata 28 yaitu terdapat pada interval kedua antara 23 - 28. Dapat disimpulkan bahwa rata-rata minat belajar peserta didik MTs Aisyiyah Ujung Belakang Olo Padang adalah rendah.

\section{Pengujian Hipotesis}

Dalam penelitian ini hipotesis alternatif yang akan diuji adalah "terdapat korelasi antara metode mengajar pendidik dengan minat belajar peserta didik di MTs Aisyiyah Ujung Belakang Olo Padang."

Setelah dilakukan analisis dengan bantuan SPSS dengan uji korelasi dengan n 26 responden harga $\mathrm{r}$ tabel 0,388 . Setelah dilakukan uji korelasi dari data metode mengajar pendidik dengan minat belajar peserta didik diperoleh harga $r$ hitung 0,778 dengan taraf signifikan 5\%. Bila dibandingkan antara $\mathrm{r}$ hitung dengan $\mathrm{r}$ tabel, maka $\mathrm{r}$ hitung lebih kecil dari $r$ tabel. Hal ini berarti Ha diterima dan Ho ditolak.

Berdasarkan perhitungan di atas ditarik kesimpulan bahwa metode mengajar pendidik (X) mempunyai hubungan dengan minat belajar peserta didik (Y). Dengan demikian Hipotesis alternatif (Ha) dalam penelitian ini berbunyi: "terdapatnya korelasi antara metode mengajar pendidik dengan minat belajar peserta didik di MTs Aisyiyah Ujung Belakang Olo Padang," dan dapat diterima.

\section{Pembahasan Hasil Penelitian}

Berdasarkan hasil penelitian yang telah dikemukakan di atas, terlihat bahwa kedua variabel yaitu antara variabel metode mengajar pendidik dengan variabel minat belajar peserta didik mempunyai korelasi (hubungan). Dengan demikian lebih banyak lagi faktor-faktor yang memiliki hubungan yang lebih kuat atau yang mempengaruhi antara metode mengajar pendidik dengan minat belajar peserta didik di antaranya sebagai berikut: ${ }^{19}$

\footnotetext{
${ }^{19}$ Udhaibi, "Faktor-faktor yang mempengaruhi metode mengajar," dalam http://id.shvoong.com/social-sciences/education/2238178-faktor-faktor-yang-mempengaruhimetode/\#ixzz1pLEuJMsZ (Sabtu, 17 Maret 2012 Pukul 10.36 WIB).
} 
Dinil Abrar Sulthani: Hubungan Metode Mengajar dengan Minat Belajar...

\section{Tujuan pembelajaran}

Pendidik yang bercita-cita mendidik dan mengajar peserta didik untuk menjadi manusia yang beragama, berakhlak serta bertakwa, perlu menyesuaikan metode mengajar agama dengan cara misalnya dengan menerapkan metode kelompok dan praktek ibadah, dan lain-lain. Menggunakan variasi mengajar sehingga timbul minat peserta didik untuk belajar dengan bahagia.

2. Bahan pelajaran

Materi pelajaran yang hendak disajikan harus disesuaikan dengan kemampuan serta kesiapan mental peserta didik, menyusun materi yang menarik minat Peserta didik dan disesuaikan dengan jenis metode yang akan dipergunakan, misalnya bahan pelajaran yang mengandung rangkaian banyak problem, maka metode yang digunakan adalah metode probling solving (pemecahan masalah) dan mungkin juga menggunakan metode proyek atau metode diskusi.

\section{Pendidik}

Apabila pendidik tidak lancar dalam berbicara, maka janganlah menggunakan metode ceramah, maka gunakanlah metode lain yang tidak memerlukan banyak bicara yaitu dengan cara memberikan keaktifan pada peserta didik itu sendiri, misalnya metode diskusi, problem solving dan peragaan.

\section{Peserta didik}

Maksudnya adalah "kondisi peserta didik" apakah mereka memiliki tingkat kemampuan dalam memberikan respon terhadap metode yang diterapkan pada mereka, apakah mereka bahagia dan berminat dengan pelajaran yang disampaikan. Maka penerapan suatu metode perlu disesuaikan dengan tingkat kemampuan psikologis kematangan pribadi peserta didik.

\section{Situasi mengajar}

Maksudnya adalah situasi atau lingkungan di sekitar sekolah, misalnya situasi pada saat pelajaran berlangsung udaranya sangat panas, apabila pendidik menggunakan metode ceramah sudah barang tentu tidak akan mendapatkan respon belajar yang optimal, maka seharusnya menggunakan metode peragaan atau praktek. Begitu sebaliknya, apabila situasi peserta didik sedang berada dalam kondisi semangat yang tinggi dalam belajar dan gembira maka metode ceramah juga metode diskusi bisa 
efektif, karena mereka akan memperoleh kesempatan untuk secara bebas mengeluarkan pendapatnya serta mengembangkan kepribadiannya.

Selain itu, dapat pula memperhatikan prinsip-prinsip umum yang harus dijadikan pegangan pendidik dalam melaksanakan proses belajar mengajar (Hamzah, 2008 : 7) adalah sebagai berikut: ${ }^{20}$

1. Mengajar harus berdasarkan pengalaman yang sudah dimiliki peserta didik. Apa yang telah dipelajari merupakan dasar dalam mempelajari bahan yang akan diajarkan. Oleh karena itu, tingkat kemampuan peserta didik sebelum proses belajar mengajar berlangsung harus diketahui pendidik. Tingkat kemampuan semacam ini disebut entry behavior. Entry behavior dapat diketahui diantaranya dengan melakukan pre test. Hal ini sangat penting agar proses belajar mengajar dapat berlangsung secara efektif dan efisien.

2. Pengetahuan dan keterampilan yang diajarkan harus bersifat praktis. Bahan pelajaran yang bersifat praktis berhubungan dengan situasi kehidupan. Hal ini dapat menarik minat, sekaligus dapat memotivasi belajar.

3. Mengajar harus memperhatikan perbedaan individual setiap peserta didik. Ada perbedaan individual dalam kesanggupan belajar. Setiap individu mempunyai kemampuan potensial seperti bakat dan intelegensi yang berbeda antara yang satu dengan lainnya. Oleh karena itu, mengajar harus memperhatikan perbedaan tingkat kemampuan masing-masing peserta didik.

4. Kesiapan (readiness) dalam belajar sangat penting dijadikan landasan dalam mengajar. Kesiapan adalah kapasitas (kemampuan potensial) baik bersifat fisik maupun mental untuk melakukan sesuatu. Apabila peserta didik siap untuk melakukan proses belajar, hasil belajar dapat diperoleh dengan baik. Sebaliknya bila tidak siap, tidak akan diperoleh hasil yang baik. Oleh karena itu, pembelajaran dilaksanakan kalau individu mempunyai kesiapan.

5. Tujuan pembelajaran harus diketahui peserta didik. Tujuan pembelajaran merupakan rumusan tentang perubahan perilaku apa yang diperoleh setelah prose belajar mengajar. Apabila tujuan pembelajaran diketahui, peserta didik mempunyai motivasi untuk belajar. Agar tujuan mudah diketahui, harus dirumuskan secara khusus.

\footnotetext{
${ }^{20}$ Hamzah, Perencanaan Pembelajaran, (Jakarta : PT. Bumi Aksara, 2008), hlm. 7
} 
Dinil Abrar Sulthani: Hubungan Metode Mengajar dengan Minat Belajar...

6. Mengajar harus mengikuti prinsip psikologis tentang belajar. Para ahli psikologi merumuskan prinsip, bahwa belajar itu harus bertahap dan meningkat. Oleh karena itu, dalam mengajar haruslah mempersiapkan bahan yang bersifat gradual, yaitu:

a. dari sederhana kepada yang kompleks (rumit);

b. dari konkret kepada yang abstrak;

c. dari umum (general) kepada yang kompleks;

d. dari yang sudah diketahui (fakta) kepada yang tidak diketahui (konsep yang bersifat abstrak);

e. dengan menggunakan prinsip induksi kepada deduksi atau sebaliknya; dan

f. Sering menggunakan reinforcement (penguatan).

\section{E. Penutup}

Pendidik seyogyanya mengetahui dan memahami berbagai macam metode mengajar yang sangat menentukan minat dan keinginan peserta didik untuk tetap belajar dengan serius dan bahagia. Dan juga mengetahui, mengevaluasi dan melaksanakan seluruh unsur, baik dari faktor-faktor yang mempengaruhi metode mengajar maupun dari faktor-faktor yang mempengaruhi minat belajar, minat belajar peserta didik akan tinggi, pendidik menyampaikan materi dengan bermutu hingga tercapailah tujuan pembelajaran yang telah dirumuskan bersama.

\section{F. Daftar Pustaka}

A. Muri Yusuf, Metodologi Penelitian, Padang: UNP Press, 2007

Burhan Bugin, Metodologi Penelitian Kuantitatif, Jakarta: Kencana, 2005

Darmasyah, Strategi Pembelajaran Menyenangkan dengan Humor, (Jakarta: Bumi Aksara, 2010

Etta Mamang Sangadji dan Sopiah, Metodologi Penelitian - Pendekatan Praktis dalam Penelitian, Yogyakarta: CV. Andi Offset, 2010

Hamzah, Perencanaan Pembelajaran, Jakarta: PT. Bumi Aksara, 2008

Margono, Metodologi Penelitian Pendidikan, Jakarta: PT.Rineka Cipta, 2009

Nana Syaodih Sukmadinata, Metode Penelitian Pendidikan, Bandung: PT Remaja Rosdakarya, 2010 
Rosi Mardayani, "Korelasi Gaya Mengajar Guru terhadap Motivasi dan Aktivitas Belajar Siswa SMA Pertiwi 2 Padang," Skripsi, FAI UMSB Padang, 2010, tidak diterbitkan.

Slameto, Belajar dan Faktor-faktor yang Mempengaruhi, Jakarta: PT. Rineka Cipta, 2010

Sugiyono, Metode Penelitian Kuantitatif, Kualitatif dan $R \& D$, Bandung: Alfabeta, 2008

Syaiful Bahri Djamarah dan Aswan Rais, Strategi Belajar Mengajar, Jakarta: PT. Rineka Cipta, 2006

Udhaibi, "Faktor-faktor yang mempengaruhi metode mengajar, dalam http://id.shvoong.com/social-sciences/education/2238178-faktor-faktor-yangmempengaruhi-metode/\#ixzz1pLEuJMsZ, diakses Sabtu, 17 Maret 2012 pukul 10.36 WIB. 